\title{
Diatom community biodiversity in an Alpine protected area: a study in the Maritime Alps Natural Park
}

\author{
Elisa FALASCO* and Francesca BONA \\ Dipartimento di Biologia Animale e dell'Uomo, Università di Torino, Via Accademia Albertina 13, I-10123 Torino, Italy \\ *e-mail corresponding author: elisa.falasco@unito.it
}

\begin{abstract}
As part of the "All Taxa Biodiversity Inventories" (ATBIs) coordinated by the European Distributed Institute of Taxonomy (EDIT), we analysed diatom communities colonizing different habitats of the Valasco Valley (Maritime Alps Natural Park). The aim of this research was to shed light on the diatom richness in an Alpine context through i) the collection of data concerning diatom communities inhabiting an unexplored watershed of the Maritime Alps Natural Park, including all of the most important aquatic habitats (comparison among river, springs and peat bogs) and assemblages (epilithic and epiphytic diatom communities); ii) analysis of the main environmental factors driving the development of diatom communities in different habitats. We completed a list of 174 diatom taxa. In general, river samples were poorer in terms of species richness than spring and peat bog ones, probably due to the selective role of the fast flow, while springs sheltered the highest biodiversity of the Valasco Valley. Peat bog communities were mainly composed of acidophilous taxa, sometimes planktonic and forming colonies. Epilithic and epiphytic samples did not show significant differences in terms of composition and biodiversity, even though it was statistically possible to identify indicator species for each assemblage. The study also highlighted the presence of several taxa included in the German Red List as endangered or decreasing, especially in the epiphytic samples. Since the water nutrient level and substrate geology were similar among habitats, the main environmental factors shaping Valasco diatom communities were water velocity and $\mathrm{pH}$.
\end{abstract}

Key words: Valasco Valley, biodiversity, epilithic, epiphytic, springs, peat bogs

\section{INTRODUCTION}

Despite the effort to significantly reduce biodiversity loss by 2010, recent research has confirmed the extinction of several plant and animal species listed as endangered in the IUCN Red Lists, while allochthonous taxa are increasing globally (Butchart et al. 2010). Therefore, fragile ecosystems such as Alpine streams should be carefully monitored, as they are exposed to extreme conditions due to their harsh nature (Cantonati et al. 2001; Cantonati \& Spitale 2009) and human exploitation (Fránková et al. 2009). For this reason, the analysis of biological assemblages inhabiting protected areas is a useful tool to establish reference and autochthonous communities not affected by human pressure and to identify endangered species that should be protected (Werum 2001; Fránková et al. 2009).

Benthic diatoms are regularly used as biological indicators for the environmental assessment of river water quality (included in the Water Framework Directive 2000/60). The analysis of diatom communities is a tool to guarantee an ecological and sustainable use of the water resources and the correct elaboration of guidelines for their preservation. In Italy, studies analysing diatom assemblages in high mountain habitats mainly cover the Eastern Alps (Cantonati 1998a, 1998b, 1999; Cantonati \& Ortler 1998; Cantonati \& Pipp 2000; Cantonati 2001; Cantonati et al. 2001; Cantonati \& Lange-Bertalot 2006; Cantonati et al. 2006; Cantonati et al. 2007; Cantonati \& Spitale 2009), while data on the Western Alps are more recent (Battegazzore et al. 2004; Falasco et al. 2007; Bona et al. 2008; Falasco et al. 2008; Mobili et al. 2008; Falasco et al. 2009a; Bona et al. 2011).

High mountain streams are extremely oligotrophic ecosystems where the geology of the substrate represents an important environmental factor in shaping diatom communities. On the one hand, siliceous substrates shelter the highest biodiversity, with indicator species characteristic of low Ca water content. At the local scale, current velocity and $\mathrm{pH}$ are the most important variables influencing diatom community composition since the geology is the same among habitats (Sabater \& Roca 1992; Cantonati \& Spitale 2009). On the other hand, the importance of the substrate typology (lithic or plants) is still poorly understood and controversial: while Bertrand et al. (2004) showed no significant differences between communities developed on cobbles or macrophytes, Fránková et al. (2009) hypothesized a specific relationship between Sphagnum and diatoms. Nevertheless, studies on this topic are still rare.

In high mountains, springs usually shelter high biodiversity due to low variability of the environmental factors over the seasons. Because of their low nutrient content, moderate water flow and constant temperature, springs can be considered suitable habitats for a wide range of species (Cantonati 1998a, 1998b, 1999). Indeed, springs offer protection for endangered and rare 


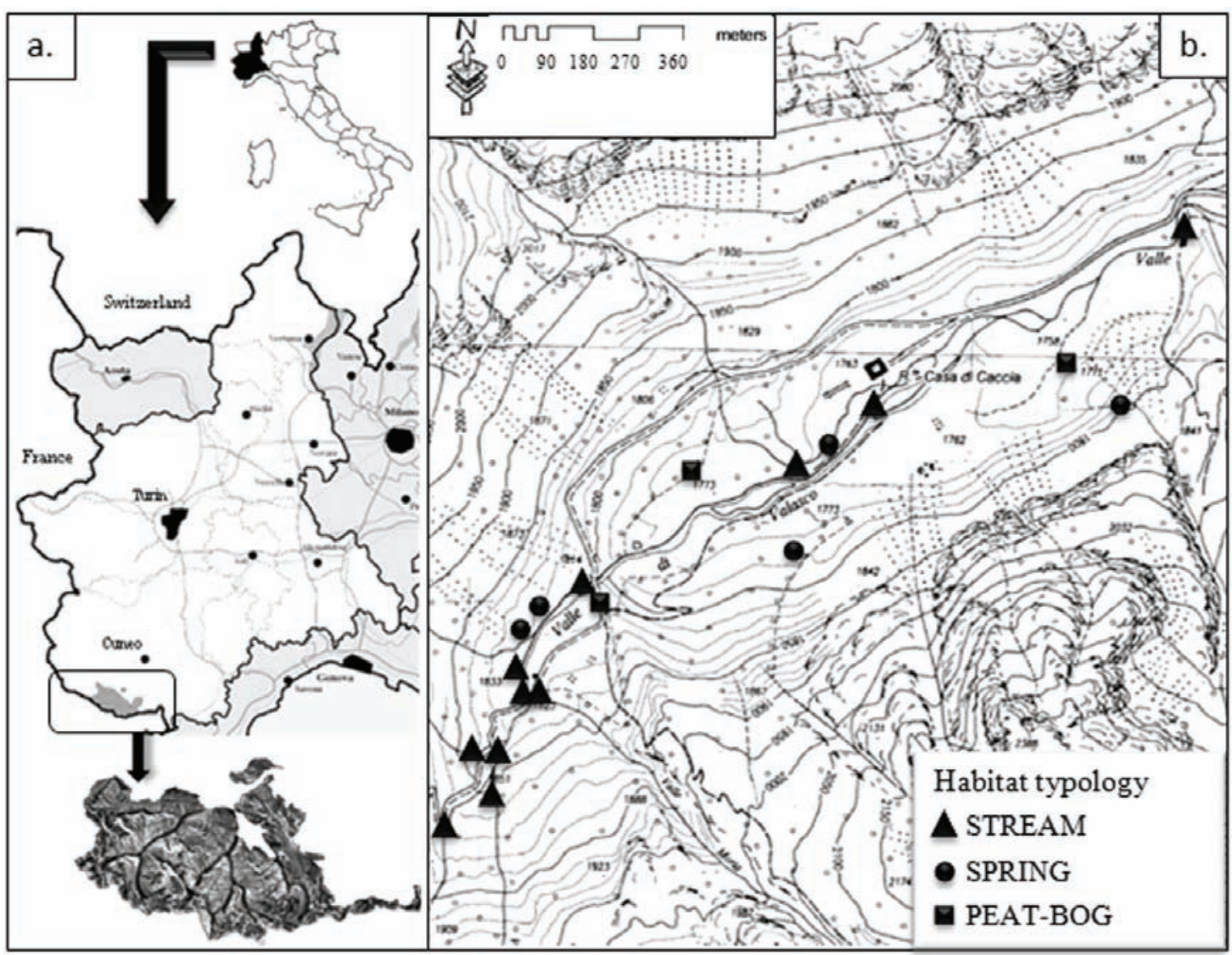

Fig. 1. a. Maritime Alps Natural Park location; b. Sampling site locations and relative habitat type.

taxa in addition to the common oligosaprobous ones (Cantonati 2001; Cantonati \& Spitale 2009). At present, the only Red List available for evaluating the conservation status of diatom species is the German one (LangeBertalot \& Steindorf 1996): there are few historical literature data on diatom distribution and conservation status from other European countries.

This research, carried out as part of the "All Taxa Biodiversity Inventories" (ATBI), was aimed at the elaboration of plant and animal check-lists for the Maritime Alps Natural Park. We examined three different habitat types in the Valasco Valley (the main Valasco River, some rheocrene springs and peat bogs), collecting samples from stones and submerged plants (epilithic and epiphytic samples). The comparison with the German Red List provided information on the presence of rare or endangered species. In addition to the production of a complete list of diatom taxa colonizing the Valasco Valley, this research aims to provide important information concerning the ecological preferences of diatom species in relation to the most important environmental variables.

\section{METHODS}

The Italian Maritime Alps Natural Park (Fig. 1a) is located in the southernmost section of the Alpine chain close to the French border. It has been twinned with the
French Mercantour National Park since 1987 but it was officially established only in 1995 . Due to its proximity to the Ligurian Sea and the presence of high peaks (over 3000 m a.s.l.), the Maritime Alps Natural Park offers a heterogeneous habitat for animals and plants, with very high biodiversity.

The present study was conducted in the Valasco Valley (1760-1832 m a.s.l.). The principal watercourse is the Valasco River, flowing in the valley bottom where there are also many small springs and peat bogs.

In summer 2009, we sampled 19 sites representing different habitat types: 11 sites in the main river, 5 in small rheocrene springs and 3 in peat bogs (Fig. 1b). Permanently wet springs and peat bogs were chosen. At each sampling site, we evaluated the main physical and chemical parameters by means of a multiparametric probe (HYDROLAB QUANTA): conductivity, dissolved oxygen, $\mathrm{pH}$ and temperature. We recorded the water velocity in three different sections of each transect with a current meter (HYDRO-BIOS KIEL). Water quality parameters $\left(\mathrm{N}-\mathrm{NH}_{4}, \mathrm{~N}-\mathrm{NO}_{3}, \mathrm{P}-\mathrm{PO}_{4}, \mathrm{BOD}_{5}, \mathrm{Ca}\right.$ and water hardness) were analysed by means of a $\mathrm{Dr}$ Lange LASA 100 spectrophotometer with analysis kits (LCK 304; LCK 554; LCK 327; LCK 339; LCK 349).

When possible, we collected diatom communities from different substrates (31 samples from 19 sites). We sampled the epilithon by randomly choosing at least five 
Tab. 1. Physical and chemical parameters recorded in the field and analysed in the laboratory. $\mathrm{R}=$ river, $\mathrm{S}=$ springs and $\mathrm{P}=\mathrm{peat}-$ bogs; $\mathrm{EL}=$ =pilithic sample, $\mathrm{EP}=$ =piphytic sample. $\mathrm{COND}=$ conductivity; $\mathrm{T}=$ temperature; $\mathrm{V}=$ water velocity (mean values); HARD=hardness. * below the instrument detection limit.

\begin{tabular}{|c|c|c|c|c|c|c|c|c|c|c|c|c|c|c|c|}
\hline \multirow{2}{*}{$\begin{array}{l}\text { Site } \\
\text { Code }\end{array}$} & \multirow{2}{*}{$\begin{array}{l}\text { Site } \\
\text { Type }\end{array}$} & \multicolumn{2}{|c|}{ Sample Type } & \multirow{2}{*}{$\begin{array}{l}\text { Cond. } \\
\left(\mu \mathrm{S} \mathrm{cm}^{-1}\right)\end{array}$} & \multirow{2}{*}{$\begin{array}{c}\mathrm{O}_{2} \\
\left(\mathrm{mg} \mathrm{L}^{-1}\right)\end{array}$} & \multirow{2}{*}{$\begin{array}{c}\mathrm{O}_{2} \\
(\%)\end{array}$} & \multirow[t]{2}{*}{$\mathrm{pH}$} & \multirow{2}{*}{$\begin{array}{c}\mathrm{T} \\
\left({ }^{\circ} \mathrm{C}\right)\end{array}$} & \multirow{2}{*}{$\begin{array}{c}\mathrm{V} \\
\left(\mathrm{m} \mathrm{s}^{-1}\right)\end{array}$} & \multirow{2}{*}{$\begin{array}{l}\mathrm{BOD}_{5} \\
\left(\mathrm{mg} \mathrm{L}^{-1}\right)\end{array}$} & \multirow{2}{*}{$\begin{array}{c}\mathrm{Ca} \\
\left(\mathrm{mg} \mathrm{L}^{-1}\right)\end{array}$} & \multirow{2}{*}{$\begin{array}{l}\text { Hard } \\
\left({ }^{\circ} \mathrm{dH}\right)\end{array}$} & \multirow{2}{*}{$\begin{array}{l}\mathrm{N}-\mathrm{NH}_{4} \\
\left(\mathrm{mg} \mathrm{L}^{-1}\right)\end{array}$} & \multirow{2}{*}{$\begin{array}{l}\mathrm{N}^{-\mathrm{NO}_{3}} \\
\left(\mathrm{mg} \mathrm{L}^{-1}\right)\end{array}$} & \multirow{2}{*}{$\begin{array}{c}\mathrm{P}^{-\mathrm{PO}_{4}} \\
\left(\mathrm{mg} \mathrm{L}^{-1}\right)\end{array}$} \\
\hline & & EL & EP & & & & & & & & & & & & \\
\hline 9042 & $\mathrm{R}$ & + & + & 19 & 9.85 & 87.8 & 7.59 & 8.00 & 0.52 & 1.23 & 5.73 & 0.80 & 0.020 & 0.237 & 0.044 \\
\hline 9044 & $\mathrm{R}$ & + & + & 21 & 9.70 & 81.5 & & 8.00 & 0.26 & 0.00 & 5.63 & 0.79 & 0.020 & 0.283 & 0.011 \\
\hline 9045 & $\mathrm{R}$ & + & + & 23 & 10.25 & 81.2 & & 5.55 & 0.97 & 1.31 & 7.30 & 1.02 & 0.028 & 0.063 & 0.007 \\
\hline 9046 & $\mathrm{R}$ & + & & 24 & 10.52 & 84.9 & & 6.66 & 0.32 & 0.20 & 5.74 & 0.80 & 0.018 & 0.313 & 0.014 \\
\hline 9047 & $\mathrm{R}$ & + & & 14 & 8.33 & 79.3 & 6.99 & 13.27 & 0.3 & 0 & 5.55 & .78 & 24 & 0.197 & $0.0005^{*}$ \\
\hline 9048 & $\mathrm{R}$ & + & & 19 & 9.45 & 77.7 & 7.02 & 7.04 & 0.3 & 0.64 & 7.7 & .08 & 0.024 & 0.119 & 0.008 \\
\hline 9049 & $\mathrm{R}$ & + & & 20 & 8.74 & 77.3 & 6.95 & 9.78 & 0.46 & 0.78 & 7.03 & 0.99 & 0.047 & 0.260 & 0.015 \\
\hline 9050 & $\mathrm{R}$ & + & + & 16 & 7.39 & 73.1 & 6.66 & 14.98 & 0.09 & 1.00 & 6.31 & 0.88 & 0.031 & 0.148 & 0.003 \\
\hline 9054 & $\mathrm{R}$ & + & & 20 & 9.32 & 81.5 & 6.81 & 9.69 & 0.67 & 4.43 & 6.59 & 0.93 & 0.028 & 0.236 & 0.006 \\
\hline 9056 & $\mathrm{R}$ & + & & 15 & 9.97 & 97.3 & 6.80 & 12.99 & 0.51 & 0.44 & 5.08 & 0.71 & 0.030 & 0.080 & 0.010 \\
\hline 9058 & $\mathrm{R}$ & + & + & 20 & 12.73 & 110.0 & 6.64 & 7.88 & 0.60 & 1.66 & 9.62 & 1.35 & 0.022 & 0.311 & 0.003 \\
\hline 9051 & $\mathrm{~S}$ & + & + & 19 & 9.40 & 77.3 & 6.75 & 7.4 & $0.05^{*}$ & & 6.14 & 0.86 & & & 0.005 \\
\hline 9052 & $\mathrm{~S}$ & + & + & 18 & 9.14 & 75.9 & 6.30 & 7.29 & $0.05^{*}$ & 2.5 & 8.0 & 1.13 & 0.026 & 0.271 & 0.006 \\
\hline 9055 & $\mathrm{~S}$ & + & + & 16 & 8.22 & 70.3 & 6.03 & 8.6 & $0.05^{*}$ & 0.99 & 4.94 & 0.69 & 0.029 & 0.164 & 0.010 \\
\hline 9059 & $\mathrm{~S}$ & + & & 13 & 6.58 & 104.0 & 6.48 & 6.48 & $0.05^{*}$ & 4.79 & 4.08 & 0.57 & 0.044 & 0.108 & 0.008 \\
\hline 9061 & $\mathrm{~S}$ & + & + & 27 & 12.30 & 98.9 & 6.37 & 5.34 & $0.05^{*}$ & 1.78 & 7.57 & 1.06 & 0.038 & 0.816 & 0.001 \\
\hline 9053 & $\mathrm{P}$ & + & + & 26 & & 75.5 & 6.63 & 6.81 & $0.05 *$ & 0.91 & 5.96 & 0.88 & 0.032 & 0.160 & $0.0005^{*}$ \\
\hline 9057 & $\mathrm{P}$ & + & + & 17 & 9.38 & 96.2 & 6.68 & 15.3 & $0.05^{*}$ & 1.30 & 6.41 & 0.90 & 0.049 & 0.207 & 0.012 \\
\hline 9060 & $\mathrm{P}$ & + & + & 21 & 10.00 & 95.2 & 6.17 & 12.01 & $0.05 *$ & 7.92 & 7.85 & 1.10 & 0.025 & 0.268 & $0.0005^{*}$ \\
\hline
\end{tabular}

cobbles along each sampling transect (Kelly et al. 1998). The epiphytic communities were collected from the dominant macrophytes along the transect, including bryophytes and entire living plants, by squeezing and cutting entire portions of them (Cantonati et al. 2007). In order to exclude moisture content variability, we chose only completely submerged substrates. All 31 samples were treated with hydrogen peroxide (100 vol.)

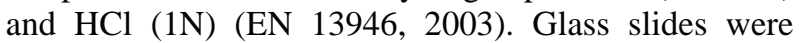
mounted with Naphrax ${ }^{\circledR}$ and analysed under a Leitz Diaplan microscope with a $100 \times$ immersion objective. Diatoms were identified mainly according to Krammer \& Lange-Bertalot (1986-1991a, b), Lange-Bertalot \& Metzeltin (1996), Krammer (1997a, b), Reichardt (1999), Lange-Bertalot (2001), Krammer (2000; 2002; 2003) and Werum \& Lange-Bertalot (2004). In a first stage of the analysis, we identified all the species on the whole glass slides in order to complete a check-list of the recorded species. Later, we defined the relative abundances by identifying at least 400 valves per sample.

Significant differences in physical and chemical parameters and biological indices (IPS, TID and diversity indices) among habitat and substrate types were highlighted with the non-parametric Kruskal-Wallis test (SPSS Statistics 17.0). Multivariate analyses were carried out with PC-ORD software (McCune \& Mefford 1999). In particular, Canonical Correspondence Analysis (CCA), Indicator Species Analysis (ISA), Multiresponse Permutation Procedure (MRPP) and Non-metric Multidimensional Scaling (NMS) were performed on biological communities, while Principal Component Analysis (PCA) was applied to the environmental dataset. ISA was used to define significantly characteristic species of habitats (river, peat bogs and springs) and assemblages (epilithic and epiphytic samples). NMS of diatom assemblages was used to test similarities and differences in diatom assemblages sampled in different habitat types and on different substrates. We set the NMS by choosing a random starting configuration: 40 runs with real data and SORENSEN (Bray-Curtis) as the distance measure. MRPP was used to test the hypothesis of no differences between the groups obtained from the NMS analysis. PCA was used to reduce the environmental dataset to a synthetic matrix to be used in the CCA analysis. The latter analysis was performed to better understand the relationships among environmental parameters and diatom communities.

\section{RESULTS}

\subsection{Physical and chemical parameters}

Physical and chemical parameters detected in the water column are shown in table 1 . All the sampling sites were located on a siliceous substrate; indeed, the Ca concentrations were very low (below $10 \mathrm{mg} \mathrm{L}^{-1}$ ). In general, no differences were found among the three sampled habitat types in terms of nutrient content and conductivity: all the sites could be classified as oligotrophic, with low electrolyte content and low organic loading. The highest value of $\mathrm{BOD}_{5}$ was detected in a peat bog (site 9060). As expected, the current velocity was significantly higher in the main river than in springs or peat bogs, where the flow was below the instrument detection limit. Moreover, the $\mathrm{pH}$ was significantly lower in peat bogs than in the other habitat types ( $p$ $<0.01$; river $>$ springs $>$ peat bogs).

\subsection{Diatom communities}

In total, 174 taxa belonging to 41 genera were recognized in the samples (see Appendix 1). In general, 
Tab. 2. Typical assemblages of the three habitat types. Taxa were selected according to their abundance ( $>3 \%$ in at least one sample) and frequency (recorded in at least $25 \%$ of the samples belonging to a certain habitat type). Taxa are listed in order of abundance.

\begin{tabular}{c|l}
\hline \multirow{2}{*}{ RIVER } & $\begin{array}{l}\text { Achnanthidium minutissimum, Diatoma mesodon, Fragilaria arcus, Achnanthidium lineare, Fragilaria rumpens, Diatoma hyemalis, } \\
\text { Diatoma sp., Gomphonema parvulum var. exilissimum, Planothidium haynaldii, Achnanthidium pyrenaicum, Encyonema silesiacum, } \\
\text { Gomphonema pseudotenellum, Gomphonema micropus, Planothidium lanceolatum, Encyonopsis minuta, Gomphonema pumilum } \\
\text { var. elegans, Nitzschia inconspicua, Neofragilaria virescens, Cymbella hantzschiana var. hantzschiana }\end{array}$ \\
SPRING & $\begin{array}{l}\text { Diatoma mesodon, Achnanthidium minutissimum, Neofragilaria virescens, Achnanthes daonensis, Psammothidium oblongellum, } \\
\text { Fragilaria rumpens, Diatoma sp., Aulacoseira alpigena, Gomphonema parvulum var. exilissimum, Encyonema silesiacum, } \\
\text { Fragilaria arcus, Brachysira brebissonii, Eunotia minor, Eunotia exigua var. tenella, Staurosira venter, Achnanthidium pyrenaicum, } \\
\text { Achnanthidium lineare, Meridion circulare, Stauroforma exiguiformis, Diadesmis perpusilla, Aulacoseira pfaffiana }\end{array}$ \\
& $\begin{array}{l}\text { Achnanthidium minutissimum, Tabellaria flocculosa, Achnanthes daonensis, Aulacoseira alpigena, Fragilaria rumpens, Staurosira } \\
\text { venter, Psammothidium oblongellum, Eunotia exigua var. tenella, Diatoma mesodon, Brachysira brebissonii, Diatoma sp., } \\
\text { Gomphonema parvulum var. exilissimum, Achnanthidium lineare, Neofragilaria virescens, Aulacoseira pfaffiana }\end{array}$ \\
\hline
\end{tabular}

Tab. 3. Number of recorded species in the whole glass slide and in the inventories; main diatom and diversity indices. $\mathrm{R}=$ =river, $\mathrm{S}=$ springs and $\mathrm{P}=$ =peat-bogs; $\mathrm{EL}=$ epilithic sample, $\mathrm{EP}=$ epiphytic sample. $\mathrm{N}$ tot= number of species identified in the whole glass slide; $\mathrm{N}$ inv= number of species identified during the inventories (out of 400 individuals); B-P=Berger-Parker; J= Equitability; Ev= Evenness; Men= Menhinick; H= Shannon; 1-D= Simpson.

\begin{tabular}{|c|c|c|c|c|c|c|c|c|c|c|c|}
\hline \multirow[t]{2}{*}{ Code Site } & \multirow[t]{2}{*}{ Type } & \multirow[t]{2}{*}{$\mathrm{N}$ tot } & \multirow[t]{2}{*}{$\mathrm{N}$ inv } & \multicolumn{2}{|c|}{ Diatom Indices } & \multicolumn{6}{|c|}{ Diversity Indices } \\
\hline & & & & IPS/20 & TID/4 & B-P & $\mathrm{J}$ & Ev & Men & $\mathrm{H}$ & 1-D \\
\hline 9042 & R-EL & 37 & 17 & 19.2 & 1.09 & 0.54 & 0.54 & 0.54 & 0.97 & 2.41 & 0.66 \\
\hline 9042 & R-EP & 31 & 24 & 19.6 & 1.00 & 0.59 & 0.52 & 0.52 & 1.26 & 2.48 & 0.63 \\
\hline 9044 & R-EL & 37 & 19 & 19.6 & 1.00 & 0.41 & 0.66 & 0.65 & 0.94 & 2.87 & 0.78 \\
\hline 9044 & R-EP & 38 & 28 & 19.5 & 0.97 & 0.46 & 0.56 & 0.56 & 1.43 & 2.74 & 0.73 \\
\hline 9045 & R-EL & 17 & 14 & 19.9 & 0.86 & 0.31 & 0.62 & 0.62 & 0.75 & 2.48 & 0.77 \\
\hline 9045 & R-EP & 29 & 17 & 19.0 & 0.78 & 0.53 & 0.52 & 0.52 & 0.94 & 2.29 & 0.66 \\
\hline 9046 & R-EL & 23 & 21 & 19.7 & 0.88 & 0.28 & 0.73 & 0.73 & 1.11 & 3.30 & 0.85 \\
\hline 9047 & R-EL & 21 & 18 & 17.1 & 2.18 & 0.40 & 0.62 & 0.62 & 0.96 & 2.72 & 0.77 \\
\hline 9048 & R-EL & 16 & 15 & 19.8 & 0.95 & 0.53 & 0.52 & 0.52 & 0.79 & 2.14 & 0.65 \\
\hline 9049 & R-EL & 19 & 15 & 19.6 & 0.82 & 0.40 & 0.67 & 0.67 & 0.83 & 2.83 & 0.78 \\
\hline 9050 & R-EL & 30 & 22 & 19.7 & 1.03 & 0.68 & 0.42 & 0.42 & 1.15 & 1.91 & 0.52 \\
\hline 9050 & R-EP & 31 & 21 & 19.5 & 1.05 & 0.55 & 0.56 & 0.56 & 1.09 & 2.52 & 0.66 \\
\hline 9054 & R-EL & 18 & 14 & 19.9 & 0.88 & 0.51 & 0.50 & 0.50 & 0.74 & 2.00 & 0.64 \\
\hline 9056 & R-EL & 18 & 14 & 19.9 & 0.96 & 0.49 & 0.48 & 0.48 & 0.74 & 1.87 & 0.65 \\
\hline 9058 & R-EL & 17 & 14 & 19.7 & 0.98 & 0.57 & 0.51 & 0.51 & 0.77 & 2.08 & 0.63 \\
\hline 9058 & R-EP & 31 & 18 & 19.5 & 0.96 & 0.25 & 0.73 & 0.73 & 0.98 & 3.20 & 0.85 \\
\hline 9051 & S-EL & 37 & 19 & 17.7 & 1.11 & 0.32 & 0.70 & 0.70 & 1.23 & 3.50 & 0.85 \\
\hline 9051 & S-EP & 29 & 18 & 16.7 & 1.12 & 0.29 & 0.71 & 0.71 & 1.07 & 3.28 & 0.84 \\
\hline 9052 & S-EL & 32 & 24 & 19.6 & 0.86 & 0.35 & 0.72 & 0.72 & 1.29 & 3.45 & 0.84 \\
\hline 9052 & S-EP & 31 & 25 & 18.6 & 0.92 & 0.29 & 0.66 & 0.66 & 1.36 & 3.20 & 0.83 \\
\hline 9055 & S-EL & 45 & 38 & 18.6 & 1.13 & 0.15 & 0.83 & 0.82 & 1.95 & 4.39 & 0.93 \\
\hline 9055 & S-EP & 30 & 18 & 19.4 & 0.94 & 0.40 & 0.59 & 0.59 & 1.03 & 2.67 & 0.75 \\
\hline 9059 & S-EL & 29 & 29 & 18.7 & 1.00 & 0.18 & 0.73 & 0.73 & 1.44 & 3.53 & 0.88 \\
\hline 9061 & S-EL & 31 & 24 & 18.7 & 0.91 & 0.24 & 0.68 & 0.68 & 1.27 & 3.25 & 0.85 \\
\hline 9061 & S-EP & 18 & 17 & 19.1 & 0.94 & 0.27 & 0.77 & 0.77 & 1.07 & 3.13 & 0.84 \\
\hline 9053 & P-EL & 24 & 18 & 17.4 & 1.28 & 0.24 & 0.75 & 0.75 & 0.94 & 3.23 & 0.85 \\
\hline 9053 & P-EP & 34 & 22 & 17.4 & 1.51 & 0.20 & 0.73 & 0.73 & 1.27 & 3.55 & 0.88 \\
\hline 9057 & P-EL & 29 & 22 & 19.2 & 1.01 & 0.44 & 0.61 & 0.61 & 1.18 & 2.81 & 0.75 \\
\hline 9057 & P-EP & 42 & 31 & 18.9 & 1.05 & 0.38 & 0.66 & 0.66 & 1.64 & 3.38 & 0.81 \\
\hline 9060 & P-EL & 36 & 25 & 18.7 & 0.92 & 0.35 & 0.68 & 0.68 & 1.27 & 3.21 & 0.83 \\
\hline 9060 & P-EP & 37 & 18 & 18.9 & 0.86 & 0.57 & 0.56 & 0.56 & 1.07 & 2.59 & 0.65 \\
\hline
\end{tabular}

communities were composed of xeno-oligosaprobous taxa, characteristic of high-altitude streams with low Ca and electrolyte content. The most frequent taxa were Achnanthidium minutissimum s.l. (detected in all the samples), Achnanthidium daonense, Diatoma mesodon, Encyonema silesiacum, Fragilaria rumpens, Gomphonema parvulum var. exilissimum (recorded in at least $87 \%$ of the samples).

The numbers of taxa recorded in the three habitat types were significantly different $(p<0.01)$ : springs $>$ peat bogs>river. Spring communities presented the highest number of taxa: 100 species in 5 samples. River communities were generally composed of circumneutral (ca 70\%) and rheophilous taxa such as Achnanthidium lineare, Diatoma hyemalis (ISA; $p<0.05$ ), $D$. mesodon and Fragilaria arcus (ISA; $p<0.01$ ). Peat bogs had the lowest flow velocity and sheltered colonial or filamentous species such as Aulacoseira alpigena, Aulacoseira pfaffiana (ISA; $p<0.5$ ), F. rumpens and Tabellaria flocculosa (ISA; $p<0.5$ ), with a high percentage of acidophilous (ca 32\%) and acidobiontic (ca 0.5\%) taxa. Characterizing assemblages for each habitat type are proposed in table 2.

The biodiversity of diatom communities was particularly high (Tab. 3); we recorded significant differences in all the diversity indices calculated for the three 
habitats: Berger-Parker ( $p<0.01)$, Equitability ( $p$ $<0.01)$, Shannon $(p<0.001)$, Simpson $(p<0.01)$. The highest biodiversity values were obtained in springs.

The sampled sites offered suitable habitats for species of conservation interest. Indeed, about $30 \%$ of the recorded taxa were included in the Red List as "decreasing" or "endangered" (Lange-Bertalot \& Steindorf 1996). Peat bogs seem to provide the best conditions for species threatened with extinction (Naviculadicta detenta), severely endangered species (Eunotia botuliformis, Eunotia steineckii and Eunotia tetraodon) and endangered ones (Amphora inariensis, Cavinula pseudoscutiformis, Chamaepinnularia soehrensis var. hassiaca, Navicula angusta, Neidium alpinum, Neidium bisulcatum and Stauroforma exiguiformis). The highest percentage of taxa included in the Red List was found in epiphytic samples (35\% vs $28 \%$ epilithic ones).

There were no significant differences in the number of taxa or the biodiversity index values among epilithic and epiphytic assemblages. Nevertheless, nearly $17 \%$ of the detected species were exclusively found on plant substrates. The indicator species for epiphytic assemblages was Neofragilaria virescens (ISA; $p<0.05$ ), while A. lineare (ISA; $p<0.05$ ) was significantly present on lithic substrates.

\subsection{Multivariate analyses}

Non-metric multidimensional scaling (NMS) of diatom assemblages (Fig. 2) well separated communities sampled in the different habitat types: river, springs and peat-bogs (Final stress $=8.09$; i.e. good ordination with no real risk of drawing false interference).

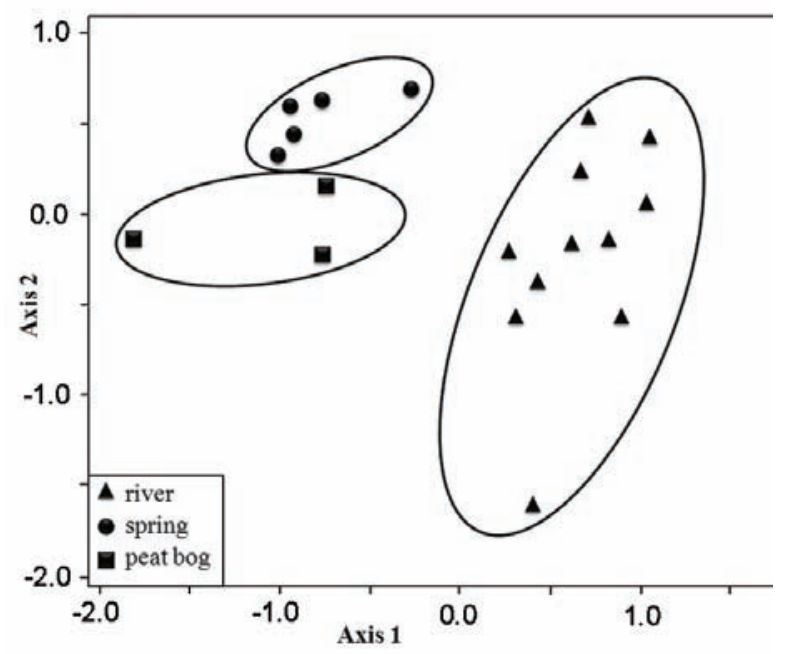

Fig. 2. Non-metric multidimensional scaling (NMS) performed on diatom communities.

Multiresponse Permutation Procedure (MRPP) confirmed the NMS findings, showing homogeneity within the three groups (A $\sim 0.1 ; p<0.001$ ) and good heterogeneity among them. Moreover, MRPP performed on epi- phytic and epilithic assemblages did not show significant separation between communities $(\mathrm{A}=0.004 ; p=$ 0.27 ). Indeed, there were no significant differences in diatom composition between epilithic and epiphytic assemblages.

Considering the small range of variation of the environmental parameters evaluated in the sampled area, we created a further environmental matrix summarizing all the parameters through a Principal Component Analysis (see Fig. 3 for PCA plot). Four significant components were obtained: PC1 explained $28.7 \%$ of variance and was mainly related to $\mathrm{pH}(0.55)$ and water velocity $(0.42)$. PC2 explained $22.58 \%$ of variance and was related to conductivity (-0.55) and Ca (-0.54). PC3 explained $12.72 \%$ and was related to dissolved oxygen $(-0.70)$. PC4 explained $11.39 \%$ and was related to $\mathrm{P}-\mathrm{PO}_{4}(0.53)$.

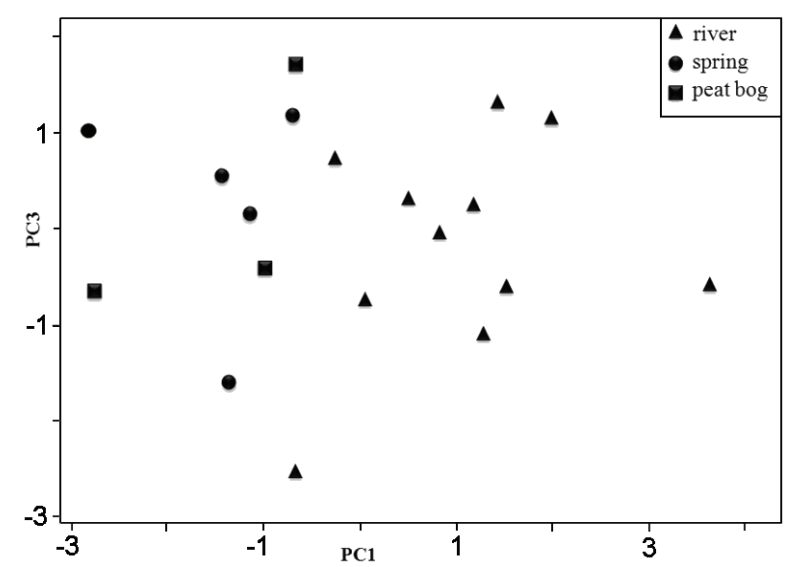

Fig. 3. Graphical representation of the Principal Component Analysis (PCA).

The coordinates (scores) of the plot were used as an environmental matrix to perform a Canonical Correspondence Analysis. The biological matrix was created by merging epiphytic and epilithic samples coming from the same site, excluding taxa detected in less than $50 \%$ of the samples and with less than $5 \%$ abundance (the final matrix included 14 taxa). The CCA summary statistics showed a high cumulative percentage of explained variance (38.8\%), mostly due to the first axis (24.8\%). The graphical representation of CCA is presented in figure 4: only axes 1 and 3 were statistically significant (Monte Carlo test, 99 runs). In general, the left of the graph contains rheophilous diatom species typical of circumneutral $\mathrm{pH}$ (PC1), while the right side contains acidophilous taxa, e.g. Eunotia exigua var. tenella and T. flocculosa. We found a good separation between Diatoma mesodon and Diatoma sp. in terms of ecological preferences: $D$. mesodon, lying in the centre of the graph, shows a more generalist behaviour than Diatoma sp. The latter was strongly correlated to PC1, preferring slightly basic $\mathrm{pH}$ and lotic conditions, but negatively correlated to PC4, i.e. mainly phosphate concentrations, thus appearing as a xenosaprobous taxon. 


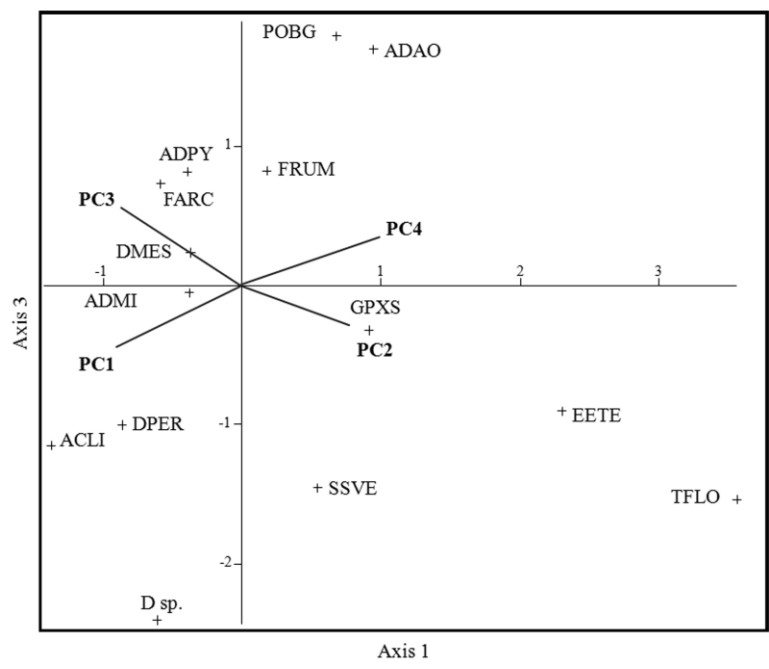

Fig. 4. Graphical representation of the Canonical Correspondence Analysis (CCA). See Annex 1 for abbreviations.

\section{DISCUSSION}

The water quality of the investigated sites was very high, with chemical and environmental features typical of mountain streams in pristine areas. The highest value of $\mathrm{BOD}_{5}$ was recorded in a peat bog, probably due to the grazing impact and static flow. Sampling sites were characterized by permanence of water, so that hydrological stability was also comparable among sampling sites and substrates. Low Ca concentrations reflected the siliceous nature of the substrate. As pointed out in other studies, when the geology and human pressure are equal within a sampling area, current velocity is the most important and selective parameter influencing diatom community composition (Sabater \& Roca 1990; Cantonati \& Spitale 2009). In our study, the $\mathrm{pH}$ and current velocity were the only parameters varying among the three habitat types and they were the driving force influencing diatom community composition. Obviously, $\mathrm{pH}$ and water velocity were significantly lower in peat bogs, with the flow often below the detection limit.

The high species richness of the Valasco Valley (174 taxa recorded at 19 sampling sites) is comparable with data obtained from other high mountain protected areas (131 taxa in 21 samples, Cantonati \& Spitale 2009; 98 taxa in 6 samples; Battegazzore et al. 2004; 188 taxa at 39 sites Fránková et al. 2009) but it is higher than the value obtained from routine monitoring in nonprotected areas (88 taxa in 51 samples, Mobili et al. 2008). The most frequent and abundant species were $A$. minutissimum s.l. and D. mesodon, characteristic of all three habitat types (especially springs), in agreement with studies carried out in comparable conditions and geology (Cantonati 1998b; Cantonati et al. 2007). In accordance with Cantonati et al. (2007), we found high percentages of Brachysira brebissonii, Eunotia minor and T. flocculosa, especially in peat bogs, while $A$. pyrenaicum was less abundant. Species recently described as typical of springs on carbonate substrates, such as Achnanthidium dolomiticum (Cantonati \& Lange-Bertalot 2006), Cymbella tridentina (Cantonati et al. 2010), Geissleria gereckei (Cantonati \& Lange-Bertalot 2009) and Encyonema sublangebertalotii (Cantonati \& Lange-Bertalot 2010), were not found at all, confirming their strong affinity for limestone.

The characteristic assemblages found in our study (Tab. 2) were mainly composed of xeno- and oligosaprobous taxa and can be considered reference communities. The comparison between these potential communities and those found in monitoring sites could be a good tool for the evaluation of human pressure in high mountain streams. Indeed, by comparing diatom community compositions in high mountain streams not included in a protected area and heavily modified from the physical point of view, we noticed that the communities in the Valasco Valley generally lacked $\beta$-mesosaprobous taxa such as Cocconeis placentula, Nitzschia dissipata, Nitzschia fonticola or $\alpha$-mesosaprobous species such as Diatoma ehrenbergii.

Indicator species of river communities were $F$. arcus, a rheophilous taxon, and $D$. hyemalis, typical of siliceous substrates (Cantonati 1998b). A. lineare preferred lithic substrates to plant ones (see ISA) and was generally correlated with higher water velocity and negatively correlated with orthophosphates (see CCA). Another interesting result of the CCA was the definition of the autoecological preferences of Diatoma sp., already recorded in other areas of the Maritime Alps Natural Park (unpublished data) but never detected in other streams of NW Italy (including Piedmont, Aosta Valley and Liguria). The CCA results indicated that Diatoma sp. is markedly stenoecious: indeed, it seemed to be a xenosaprobous taxon, adapted to living on siliceous substrates and low electrolyte contents, preferring good dissolved oxygen levels and plants as substrates. Further taxonomic investigations, both with traditional methods and recently developed techniques (such as geometric morphometric analysis; Falasco et al. 2009b; Novais et al. 2009), are necessary to clarify the nature of this taxon.

The biodiversity indices were lower in the river than in springs and peat bogs: the mean Shannon index in springs was 2.34, in accordance with Cantonati et al. (2007). Biodiversity was generally higher in the Valasco Valley than in other high-altitude streams not included in a protected area and affected by human pressure (Bona et al. 2008).

CCA and ISA revealed characteristic taxa of peat bogs: A. pfaffiana, E. exigua var. tenella and T. flocculosa, i.e. colonial species generally inhibited in lotic headwaters, with preferences for low $\mathrm{pH}$ (van Dam et al. 1994). Moreover, $N$. virescens was abundant in the Valasco Valley, mainly preferring springs and peat bogs and plants as substrate. 
The characteristic physical and chemical stability of springs and the presence of mosses and aquatic plants, thereby increasing the heterogeneity of microhabitats, allowed colonization by the highest number of taxa in all our samples and confirmed the role of springs as hot spots for biodiversity (Cantonati et al. 2006; Fránková et al. 2009). We observed no significant differences in species richness or biodiversity values between epiphytic and epilithic assemblages, confirming the observation of Bertrand et al. (2004). However, it is noteworthy that the number of species detected in epiphytic and epilithic samples was significantly higher than in samples from stones alone. About $17 \%$ of the recorded species were exclusively found on plant substrates. As pointed out by Cantonati et al. (2007), sampling of the dominant substrates (stones, mosses, surface sediment) would be an important improvement for sampling guidelines in high-altitude streams, which presently include only sampling on boulders. The sampling of plants in lithic substrates would add important data on the presence and distribution of taxa.

The highest percentage of diatom taxa included as endangered or decreasing in the German Red List (Lange-Bertalot \& Steindorf 1996) was found in peat bogs and springs. In general, endangered species showed low abundances and frequencies, the only exceptions being Amphora inariensis and Stauroforma exiguiformis (found at $16 \%$ of the sites), E. steineckii and Neidium alpinum (19\% of the samples), E. botuliformis (25\% of the sites). S. exiguiformis reached its abundance peak in one spring (6\%). However, comparison with the Red List could present some limitations. The lack of historical data on diatom taxa distribution and abundance in NW Italy prevented direct comparison with the Italian flora, leading to uncertainty in species classification, especially for the category "in decrease". In addition, some species listed as endangered in the Red List (for example, A. inariensis and $N$. angusta) seem to be frequent and well distributed in our region, as confirmed by previous studies (Battegazzore et al. 2004; Falasco et al. 2008). Moreover, the Red List has not been updated since 1996 and the percentage of taxa whose conservation status is unknown is still high. This demonstrates the importance of local and specific studies in remote areas in order to update the Red List and validate it with data from the Alpine region.

\section{CONCLUSIONS}

Despite the small sampling area, about 34\% of the species were recorded only at one sampling station, underlining the importance of the preservation of every aquatic habitat of the valley, especially peat bogs. This finding of high species diversity in small habitats confirms the results of other studies, e.g. Bertrand et al. (2004) or Cantonati \& Spitale (2009). The only impact by humans affecting the Valasco Valley is pasture, and there is a substantial presence of grazing domestic herds during the summer, but the chemistry of the aquatic ecosystems has apparently not been altered. Herd trampling can represent a mechanical disturbance, compressing and eroding peat bogs, whose recovery is particularly slow (Bracco et al. 2004). The protection of the most sensitive habitats, such as peat bogs, with temporary fences is recommended. Constructions of passageways for hikers could protect the sensitive habitats and would make visitors more aware about habitat conservation and lessen the damage from herds.

\section{ACKNOWLEDGEMENTS}

The present research was funded by the Maritime Alps Natural Park. We are grateful to Stefano Brighenti, Elisa Lorenzon and Sabrina Mossino for their help in the field and laboratory work and to Peter W. Christie for the linguistic revision. Special thanks go to Professor Lange-Bertalot for his valuable suggestions in the identification of some Eunotia species.

\section{REFERENCES}

Battegazzore, M., A. Morisi, B. Gallino \& S. Fenoglio. 2004. Environmental quality evaluation of Alpine springs in NW Italy using benthic diatoms. Diatom Res., 19: 149-165.

Bertrand, J., J.P. Renon, O. Monnier \& L. Ector. 2004. Relation "Diatomées epiphytes-bryophytes" dans les turbières du Mont Lozère (France). Vie et Milieu, 54: 59-70.

Bona, F., V. La Morgia \& E. Falasco. (2011). Predicting river diatom removal after shear stress induced by ice melting. Riv. Res. Appl.: (in press).

Bona, F., E. Falasco, S. Fenoglio, L. Iorio \& G. Badino. 2008. Response of macroinvertebrate and diatom communities to human-induced physical alteration in mountain streams. Riv. Res. Appl., 24: 1068-1081.

Bracco, F., A. Gentili, A. Minelli, M. Solari, F. Stoch \& R. Venanzoni. 2004. Le torbiere montane. Relitti di biodiversità in acque acide. In: Ministero dell'Ambiente e Tutela del Territorio (Ed), Quaderni Habitat 9, Museo Friulano di Storia Naturale.

Butchart, S.H.M., M. Walpole, B. Collen, A. van Strien, J.P.W. Scharlemann, R.E.A. Almond, J.E.M. Baillie, B. Bomhard, C. Brown, J. Bruno, K.E. Carpenter, G.M. Carr, J. Chanson, A.M. Chenery, J. Csirke, N.C. Davidson, F. Dentener, M. Foster, A. Galli, J.N. Galloway, P. Genovesi, R.D. Gregory, M. Hockings, V. Kapos, J.F. Lamarque, F. Leverington, J. Loh, M.A. McGeoch, L. McRae, A. Minasyan, M. Hernández Morcillo, T.E.E. Oldfield, D. Pauly, S. Quader, C. Revenga, J.R. Sauer, B. Skolnik, D. Spear, D. Stanwell-Smith, S.N. Stuart, A. Symes, M. Tierney, T.D. Tyrrell, J.C. Vié \& R. Watson. 2010. Global biodiversity: indicators of recent declines. Science, 328: 11641168.

Cantonati, M. 1998a. Diatom communities of springs in the Southern Alps. Diatom Res., 30: 201-220.

Cantonati, M. 1998b. Le sorgenti del Parco Adamello-Brenta. In: Cantonati, M. (Ed), Parco Documenti, Parco AdamelloBrenta. Strembo (TN): 177 pp.

Cantonati, M. 1999. Distribution and seasonality of the phytobenthos along two mountain spring streams in catchments of contrasting lithology. In: Bon, M., G. Sburlino \& V. Zuccarello (Eds), Atti XIII Convegno Gadio "Aspetti ecologici e naturalistici dei sistemi lagunari e costieri". Suppl. Boll. Mus. Civ. Stor. Nat. Venezia, 49: 357-367.

Cantonati, M. 2001. The diatom communities of the liverwort Chiloscyphus polyanthos var. rivularis in a mountain 
spring fed stream in the Adamello-Brenta Regional Park, Northern Italy. In: Jahn, R., J.P. Kociolek, A. Witkowski \& P. Compere (Eds), Lange-Bertalot-Festschrift: Studies on Diatoms. A.R.G. Gantner: 353-358.

Cantonati, M. \& H. Lange-Bertalot. 2006. Achnanthidium dolomiticum sp. nov. (Bacillariophyta) from oligotrophic mountain springs and lakes fed by dolomite aquifers. $J$. Phycol., 42: 1184-1188.

Cantonati, M. \& H. Lange-Bertalot. 2009. Geissleria gereckei sp. nov. (Bacillariophyta) from leaf-litter covered stones of very shaded carbonate mountain springs with extremely low discharge. Phycol. Res., 57: 171-177.

Cantonati, M. \& H. Lange-Bertalot. 2010. Diatom biodiversity of springs in the Berchtesgaden National Park (NorthEastern Alps, Germany), with the ecological and morphological characterization of two species new to science. Diatom Res., 25: 251-280.

Cantonati, M. \& K. Ortler. 1998. Using spring biota of pristine mountain areas for long term monitoring. In: IAHS Publ. Proceedings of the Head water '98 "Hydrology, Water Resources and Ecology in Headwaters", 248: 379-385.

Cantonati, M. \& E. Pipp. 2000. Longitudinal and seasonal differentiation of epilithic diatom communities in the uppermost sections of two mountain spring-fed streams. Verh. Int. Ver. Theor. Angew. Limnol., 27: 1591-1595.

Cantonati, M. \& D. Spitale. 2009. The role of environmental variables in structuring epiphytic and epilithic diatom assemblages in springs and streams of the Dolomiti Bellunesi National Park (south-eastern Alps). Fundam. Appl. Limnol./Arch. Hydrobiol., 174: 117-133.

Cantonati, M., R. Gerecke \& E. Bertuzzi. 2006. Springs of the Alps - sensitive ecosystems to environmental change: from biodiversity assessments to long-term studies. Hydrobiologia, 562: 59-96.

Cantonati, M., G. Corradini, I. Juttner \& E.J. Cox. 2001. Diatom assemblages in high mountain streams of the Alps and the Himalaya. Nova Hedw. Beih., 123: 37-67.

Cantonati, M., H. Lange-Bertalot, A. Scalfi \& N. Angeli. 2010. Cymbella tridentina sp. nov. (Bacillariophyta), a crenophilous diatom from carbonate springs of the Alps. $J$. North Am. Benth. Soc., 29: 775-788.

Cantonati, M., E. Rott, P. Pfister \& E. Bertuzzi. 2007. Benthic algae in springs: biodiversity and sampling methods. In: Cantonati, M., E. Bertuzzi \& D. Spitale (Eds), The spring habitat: biota and sampling methods. Museo Tridentino di Scienze Naturali,Trento: 77-112.

EN 13946. 2003. Water quality - Guidance standard for the routine sampling and pretreatment of benthic diatoms from rivers: 1-18.

Falasco, E., F. Bona, S. Fassina, L. Mobili \& L. Ector. 2007. Communautés de diatomées benthiques des cours d'eaux de haute altitude du Piémont et de la Vallée d'Aoste (Italie Nord Occidentale). In: Almeida, S.F.P., S.C. Craveiro, F. Rimet \& L. Ector (Eds), Abstract book of the XXVI ADLaF meeting "La dispersion des espèces dans un environnement changeant: effets sur les communautés de diatomées". University of Aveiro, Portugal, 26: 14.

Falasco, E., F. Bona, L. Mobili, L. Hoffmann \& L. Ector. 2008. Characterization of diatom assemblages in Alpine streams of North-West Italy. In: Jasprica, N., A. Car \& M. Čalić (Eds), Abstract book of the XX International Diatom Symposium, 20: 132.

Falasco, E., E. Ciaccio, L. Hoffmann, L. Ector \& F. Bona. 2009a. Alpine freshwater ecosystems in a protected area: a source of diatom diversity. In: Ector, L., D. Hlúbikóva, H.M. Cauchie \& L. Hoffmann (Eds), Abstract book of $7^{\text {th }}$ International Symposium "Use of Algae for Monitoring Rivers", 7: 78.

Falasco, E., S. Blanco, F. Bona, J. Gomà, D. Hlúbiková, M.H. Novais, L. Hoffmann \& L. Ector. 2009b. Taxonomy, mor- phology and distribution of the Sellaphora stroemii complex (Bacillariophyceae). Fottea, 9: 243-256.

Fránková, M., J. Bojková, A. Poulíčková \& M. Hájek. 2009. The structure and species richness of the diatom assemblages of the Western Carpathian spring fens along the gradient of mineral richness. Fottea, 9: 355-368.

Kelly, M.G., A. Cazaubon, E. Coring, A. Dell'Uomo, L. Ector, B. Goldsmith, H. Guasch, J. Hurlimann, A. Jarlman, B. Kawecka, J. Kwandrans, R. Laugaste, E.A. Lindstrom, M. Leitao, P. Marvan, J. Padisak, E. Pipp, J. Prygiel, E. Rott, S. Sabater, H. Van Dam \& J. Vizinet. 1998. Recommendations for the routine sampling of diatoms for water quality assessments in Europe. J. Appl. Phycol., 10: 215-224.

Krammer, K. 1997a. Die cymbelloiden Diatomeen. Teil 1. Allgemeines und Encyonema Part. Bibliotheca Diatomologica, 36: 1-382.

Krammer, K. 1997b. Die cymbelloiden Diatomeen. Teil 2. Encyonema part., Encyonopsis and Cymbellopsis. Bibliotheca Diatomologica, 37: 1-469.

Krammer, K. 2000. The genus Pinnularia. In: A.R.G., LangeBertalot, H. (Ed.), Diatoms of Europe. Volume 1. Gantner: Rugell: 584 pp.

Krammer, K. 2002. Cymbella. In: A.R.G., Lange-Bertalot, H. (Ed.). Diatoms of Europe. Volume 3. Gantner: Rugell: 584 pp.

Krammer, K. 2003. Cymbopleura, Delicata, Navicymbula, Gomphocymbellopsis, Afrocymbella. In: A.R.G., LangeBertalot, H. (Ed.), Diatoms of Europe. Volume 4. Gantner: Rugell: 530 pp.

Krammer, K. \& H. Lange-Bertalot. 1986. Bacillariophyceae. 1. Teil: Naviculaceae. In: Ettl, H., J. Gerloff, H. Heynig \& D. Mollenhauer (Hrsgb.). Süsswasserflora von Mitteleuropa. Bd. 2, Fischer Verlag: Stuttgart.

Krammer, K. \& H. Lange-Bertalot. 1988. Bacillariophyceae. 2. Teil: Bacillariaceae, Epithemiaceae, Surirellaceae. In: Ettl, H., J. Gerloff, H. Heynig \& D. Mollenhauer (Hrsgb.), Süsswasserflora von Mitteleuropa. Bd. 2, Fischer Verlag: Stuttgart.

Krammer, K. \& H. Lange-Bertalot 1991a. Bacillariophyceae. 3. Teil: Centrales, Fragilariaceae, Eunotiaceae. In: Ettl, H., J. Gerloff, H. Heynig \& D. Mollenhauer (Hrsgb.), Süsswasserflora von Mitteleuropa. Bd. 2, Fischer Verlag: Stuttgart.

Krammer, K. \& H. Lange-Bertalot. 1991b. Bacillariophyceae. 4. Teil: Achnanthaceae. Kritische Erg.anzungen zu Navicula (Lineolatae) und Gomphonema. In: Ettl, H., J. Gerloff, H. Heynig \& D. Mollenhauer (Hrsgb.), Süsswasserflora von Mitteleuropa. Bd. 2, Fischer Verlag: Stuttgart.

Lange-Bertalot, H. 2001. Navicula sensu stricto, 10 Genera separated from Navicula sensu lato, Frustulia. In: A.R.G., Lange-Bertalot, H. (Ed.); Diatoms of Europe. Volume 2. Gantner: Rugell: 526pp.

Lange-Bertalot, H. \& D. Metzeltin. 1996. Indicators of Oligotrophy. In: Lange-Bertalot H. (Ed.), Iconographia Diatomologica 2. Koeltz, Koenigstein: 390 pp.

Lange-Bertalot, H. \& A. Steindorf. 1996. Rote Liste der limnischen Kieselalgen (Bacillariophyceae) Deutschlands. Schriftenreihe für Vegetationskunde, 28: 633-677.

McCune, B. \& M.J. Mefford. 1999. Multivariate Analysis of Ecological Data, Version 4. MjM Software Design, Gleneden Beach, Oregon, USA.

Mobili, L., E. Falasco, F. Bona, S. Isabel, L. Viquery \& L. Ector. 2008. Diatomées benthiques des rivières de la Vallée d'Aoste (Italie): réponses aux gradients écologiques en environnement alpin. In: ADLaF (ed.), Abstract book of the XXVII ADLaF meeting, 27: 55.

Novais, M.H., S. Blanco, C. Delgado, E. Falasco, J. Gomà, D. Hlúbiková, P. Ivanov, M. Morais, L. Hoffmann \& L. Ector. 2009. Distribution and taxonomy of the Gomphonema tergestinum and $G$. rosenstockianum species complex. Fottea, 9: 257-274. 
Reichardt, E. 1999. Zur Revision der Gattung Gomphonema. Die Arten um G. affine/insigne, G. angustum/micropus, G. accuminatum sowie gomphonemoide Diatomeen aus dem Oberoligozän in Böhmen. In: A.R.G., Lange-Bertalot, H. (Ed.). Iconographia Diatomologica 8, Gantner: Rugell.

Sabater, S. \& J.R. Roca. 1990. Some factors affecting the distribution of diatom assemblages in Pyrenean springs. Freshwat. Biol., 24: 493-507.

Sabater, S. \& J.R. Roca. 1992. Ecological and biogeographical aspects of diatom distribution in Pyrenean springs, $\mathrm{Br}$. Phycol. J., 27: 203-213.
Van Dam, H., A. Mertens \& J. Sinkeldam. 1994. A coded checklist and ecological indicator values of freshwater diatoms from the Netherlands. Neth. J. Aq. Ecol., 28: 117-133.

Werum, M. 2001. Die Kieselalgengesellschaften in Quellen. Abhängigkeit von Geologie kostenlos und anthropogener Beeinflussung in Hessen (Bundesrepublik Deutschland). ISBN 13 978-3-89026-331-1. Wiesbaden: 273 pp.

Werum, M. \& H. Lange-Bertalot. 2004. Diatoms in Springs from Central Europe and elsewhere under the influence of hydrogeology and anthropogenic impacts. In: Lange-Bertalot, H. (Ed.),. Iconographia Diatomologica, 13. Koeltz, Koenigstein: 1-417.

\section{A $\quad$ P}

Appendix - Complete checklist of all the taxa detected in the samples. R.L. column refers to conservation status defined in Lange-Bertalot \& Steindorf (1996): 1 = threatened with extinction. 2 = severely endangered. $3=$ endangered. $\mathrm{D}=$ data scarce. $\mathrm{G}=$ probably endangered. $\mathrm{R}=$ rare. $\mathrm{V}=$ decreasing. $*=$ at present not considered threatened. $* *=$ surely not threatened. $\mathrm{pH}$ column represents taxa sensitivity to acidification (van Dam et al. 1994): $1=$ acidobiontic (optimal occurrence at $\mathrm{pH}<5.5$ ); $2=$ acidophilous (mainly occurring at $\mathrm{pH}<7$ ); $3=$ circumneutral (mainly occurring at $\mathrm{pH}$ values about 7); 4= alkaliphilous (mainly occurring at $\mathrm{pH}>7$ ); $5=$ alkalibiontic (exclusively occurring at $\mathrm{pH}>7$ ); $6=$ indifferent. Moist. column represents taxa moisture preferences (van Dam et al. 1994): 1= never or very rarely occurring outside water bodies; $2=$ mainly occurring in water bodies, sometimes on wet places; $3=$ mainly occurring in water bodies, also rather regularly on wet and moist places; 4= mainly occurring on wet and moist or temporarily dry places; $5=$ nearly exclusively occurring outside water bodies. The last columns represent the presence of each single taxon in the sampled habitats and assemblages.

\begin{tabular}{|c|c|c|c|c|c|c|c|c|c|c|}
\hline \multirow[t]{2}{*}{ Taxon } & \multirow[t]{2}{*}{ Code } & \multirow[t]{2}{*}{ R.L. } & \multirow[t]{2}{*}{$\mathrm{pH}$} & \multirow[t]{2}{*}{ Moist } & \multicolumn{2}{|c|}{$\mathrm{R}$} & \multicolumn{2}{|c|}{$\mathrm{S}$} & \multicolumn{2}{|c|}{$\mathrm{P}$} \\
\hline & & & & & EL & EP & EL & EP & EL & EP \\
\hline Achnanthidium daonense (Lange-Bert) Lange-Bert, Monnier et Ector & ADAO & G & 3 & 1 & + & + & + & + & + & + \\
\hline Achnanthidium lineare W. Smith & ACLI & 3 & 3 & & + & + & + & & + & + \\
\hline Achnanthidium minutissimum (Kützing) Czarnecki & ADMI & $* *$ & 3 & 3 & + & + & + & + & + & + \\
\hline Achnanthidium minutissimum (Kützing) Czarnecki fo. teratogene & ADMT & 1 & 3 & 3 & + & & & & & \\
\hline Achnanthidium minutissima var. affinis (Grunow) Bukht. & ADMF & $*$ & 4 & 1 & + & & + & & & + \\
\hline Achnanthidium pyrenaicum (Hustedt) Kobayasi & ADPY & $* *$ & 4 & & + & + & + & & & + \\
\hline Achnanthidium pyrenaicum (Hustedt) Kobayasi abnormal form & ADPT & 1 & 4 & & + & + & & & & \\
\hline Adlafia minuscula var. muralis (Grunow) Lange-Bertalot & ADMM & $* *$ & 4 & 3 & + & + & & & & \\
\hline Amphora inariensis Krammer & AINA & 3 & & & + & + & & & + & \\
\hline Amphora ovalis (Kützing) Kutzing & AOVA & $* *$ & 4 & 1 & & & + & & & \\
\hline Amphora pediculus (Kützing) Grunow & APED & $* *$ & 4 & 3 & + & + & & & & \\
\hline Aulacoseira alpigena (Grunow) Krammer & AUAL & G & 2 & 1 & + & & + & + & + & + \\
\hline Aulacoseira distans (Ehrenberg) Simonsen & AUDI & $\mathrm{G}$ & 2 & 1 & & + & & & & \\
\hline Aulacoseira pfaffiana (Reinsch) Krammer & AUPF & G & 2 & 2 & & + & + & + & + & + \\
\hline Brachysira brebissonii Ross & BBRE & $*$ & 2 & 3 & & + & + & + & + & + \\
\hline Brachysira neoexilis Lange-Bertalot & BNEO & * & 2 & 2 & + & + & + & & & \\
\hline Caloneis tenuis (Gregory) Krammer & CATE & G & 3 & 4 & + & & + & + & & \\
\hline Cavinula pseudoscutiformis (Hustedt) Mann \& Stickle & CPSE & 3 & 4 & 3 & + & & & & + & + \\
\hline Chamaepinnularia soehrensis var. hassiaca (Krasske) Lange-Bertalot & $\mathrm{CHSH}$ & 3 & 2 & 4 & & & & + & & + \\
\hline Cocconeis euglypta Ehrenberg & CPLE & $* *$ & 4 & 2 & & & & + & & \\
\hline Cocconeis neodiminuta Krammer & CNDI & $\mathrm{R}$ & & & + & & & & & \\
\hline Cocconeis pediculus Ehrenberg & CPED & $* *$ & 4 & 1 & & & & + & & \\
\hline Cocconeis placentula Ehrenberg & CPLA & & 4 & 2 & + & + & & & & \\
\hline Cocconeis pseudolineata (Geitler) Lange-Bertalot & CPPL & $\mathrm{D}$ & 4 & & + & + & & & & + \\
\hline Cyclotella atomus Hustedt & CATO & $* *$ & 4 & 1 & & & & & & + \\
\hline Cyclotella ocellata Pantocsek & COCE & $*$ & 4 & 1 & & & & & + & \\
\hline Cymbella excisa Kützing & CAEX & & 4 & 2 & + & & & + & & \\
\hline Cymbella excisiformis Krammer & CEXF & & 4 & & + & & & & & \\
\hline Cymbella hantzschiana Krammer & CHAN & & & & + & & & & & \\
\hline Cymbella helvetica Kützing & CHEL & $\mathrm{V}$ & 4 & 2 & + & & & & & \\
\hline Cymbella laevis Naegeli in Kützing & CLAE & G & 3 & & + & & & & & \\
\hline Cymbella parva (W. Smith) Kirchner in Cohn & CPAR & & & & + & & & & & \\
\hline Cymbopleura amphicephala Krammer & CBAM & $\mathrm{V}$ & 3 & 3 & & & & + & & \\
\hline Cymbopleura naviculiformis (Auerswald) Krammer & CBNA & $*$ & 3 & 2 & & + & + & & & + \\
\hline Delicata delicatula (Kützing) Krammer & DDEL & G & 4 & 3 & & & & + & & \\
\hline Denticula kuetzingii Grunow & DKUE & $*$ & 4 & 3 & + & & & & & \\
\hline Denticula tenuis Kützing & DTEN & $*$ & 4 & 3 & + & + & + & & & \\
\hline Diadesmis biceps Arnott ex Grunow & DBIC & & 4 & 4 & & & + & & & \\
\hline Diadesmis perpusilla (Grunow) D.G. Mann & DPER & $* *$ & 3 & 5 & + & + & + & + & & \\
\hline Diatoma ehrenbergii Kützing & DEHR & $* *$ & 5 & 1 & & & + & & & + \\
\hline Diatoma hyemalis (Roth) Heiberg & DHIE & $*$ & 4 & 2 & + & + & & + & & \\
\hline Diatoma mesodon Kützing & DMES & $*$ & 3 & 2 & + & + & + & + & + & + \\
\hline Diatoma moniliformis Kützing & DMON & $* *$ & 5 & & + & & + & & & \\
\hline Diatoma sp. & D sp. & & & & + & + & + & + & + & + \\
\hline
\end{tabular}

(continued) 
Appendix. Continuation

\begin{tabular}{|c|c|c|c|c|c|c|c|c|c|c|}
\hline \multirow[t]{2}{*}{ Taxon } & \multirow[t]{2}{*}{ Code } & \multirow[t]{2}{*}{ R.L. } & \multirow[t]{2}{*}{$\mathrm{pH}$} & \multirow[t]{2}{*}{ Moist } & \multicolumn{2}{|c|}{$\mathrm{R}$} & & & 1 & \\
\hline & & & & & EL & EP & EL & EP & EL & EP \\
\hline Diatoma sp. teratologica & D sp.t & & & & & + & & & & \\
\hline Encyonema caespitosum Kützing & ECAE & $* *$ & & & + & + & & & & \\
\hline Encyonema lange-bertalotii Krammer morphotype 1 & ENLB & & 3 & & & & + & & & \\
\hline Encyonema lunatum (W. Smith) Van Heurck & ENLU & & & & & + & & + & & + \\
\hline Encyonema minutum (Hilse) Mann & ENMI & $*$ & 3 & & + & + & + & + & & \\
\hline Encyonema minutum (Hilse in Rabh.) Mann fo. teratogene & ENMT & 1 & & & + & & & & & \\
\hline Encyonema neogracile Krammer & ENNG & 3 & 2 & 3 & & + & + & + & + & \\
\hline Encyonema silesiacum (Bleisch) Mann & ESLE & $*$ & 3 & 1 & + & + & + & + & + & + \\
\hline Encyonema ventricosum (Kützing) Grunow & ENVE & $*$ & 3 & & + & + & & & & \\
\hline Encyonopsis cesatii (Rabenhorst) Krammer & ECES & $*$ & 3 & 3 & + & & + & & & \\
\hline Encyonopsis falaisensis (Grunow) Krammer & ECFA & G & 0 & 3 & & + & + & + & & + \\
\hline Encyonopsis subminuta Krammer et Reichardt & ESUM & & 3 & & + & & & & & \\
\hline Encyonopsis minuta Krammer et Reichardt & ECPM & & 4 & & + & + & + & + & + & + \\
\hline Eolimna minima (Grunow) Lange-Bertalot & EOMI & $* *$ & 4 & 3 & + & + & + & + & + & + \\
\hline Eolimna subminuscula (Manguin) Moser Lange-Bertalot et Metzeltin & ESBM & $* *$ & 4 & 3 & & + & & & & \\
\hline Eucocconeis laevis (Østrup) Lange-Bertalot & EULA & $*$ & 3 & 3 & + & + & & & & \\
\hline Eunotia boreoalpina Lange-Bertalot et Nörpel-Schempp & EBOA & & & & & + & + & + & + & + \\
\hline Eunotia botuliformis Wild, Nörpel-Schempp et Lange-Bertalot & EBOT & 2 & 2 & & + & + & + & + & & + \\
\hline Eunotia diodon Ehrenberg & EDIO & $*$ & 2 & 4 & & & & & & + \\
\hline Eunotia exigua var. tenella (Grunow) Nörpel et Alles & EETE & $\mathrm{V}$ & 2 & 3 & + & + & + & + & + & + \\
\hline Eunotia glacialisfalsa Lange-Bertalot & EGFA & & & & & & + & & + & + \\
\hline Eunotia implicata Nörpel-Schempp, Lange-Bertalot et Alles & EIMP & G & 2 & 3 & & + & + & + & & \\
\hline Eunotia incisa Gregory & EINC & $*$ & 2 & 2 & & & + & & + & + \\
\hline Eunotia inflata (Grunow) Nörpel-Schempp et Lange-Bertalot & EINF & 2 & 2 & & & & + & & + & \\
\hline Eunotia meisterioides Lange-Bertalot & & & & & & & & & + & \\
\hline Eunotia minor (Kützing) Grunow & EMIN & $*$ & 2 & 4 & + & + & + & + & + & + \\
\hline Eunotia neocompacta Mayama & ENEC & & & & & & & & + & \\
\hline Eunotia paludosa Grunow in Van Heurck & EUPA & $\mathrm{V}$ & 1 & 4 & & & + & & & \\
\hline Eunotia pseudogroenlandica Lange-Bertalot \& Tagliaventi & & & & & & + & & & & \\
\hline Eunotia soleirolii (Kützing) Rabenhorst & ESOL & & 3 & 3 & & & + & & + & \\
\hline Eunotia steineckii Petersen & ESTK & 2 & 2 & & + & & & + & + & + \\
\hline Eunotia subarcuatoides Alles, Nörpel et Lange-Bertalot & ESUB & $* *$ & 1 & 3 & & & & + & & + \\
\hline Eunotia tetraodon Ehrenberg & ETET & 2 & 2 & 3 & & & & & & + \\
\hline Eunotia valida Hustedt & EVAL & $\mathrm{G}$ & 2 & 3 & & + & & & & \\
\hline Fragilaria cf. alpestris Krasske ex Hustedt & FALP & $\mathrm{V}$ & & 4 & + & + & + & & & + \\
\hline Fragilaria arcus (Ehrenberg) Cleve & FARC & $* *$ & 4 & 3 & + & + & + & & + & + \\
\hline Fragilaria arcus (Ehrenberg) Cleve fo. teratogene & FART & 1 & 4 & 3 & + & + & + & & + & + \\
\hline Fragilaria delicatissima (W. Smith) Lange-Bertalot & FDEL & $\mathrm{V}$ & 3 & 1 & & + & & & & \\
\hline Fragilaria gracilis (Øestrup) Hustedt & FGRA & $*$ & 3 & & + & & + & & + & + \\
\hline Fragilaria rumpens (Kützing) Carlson & FRUM & $*$ & 3 & & + & + & + & + & + & + \\
\hline Fragilaria rumpens (Kützing) Carlson fo. teratogene & FRUT & 1 & 3 & & + & + & + & & + & + \\
\hline Fragilaria vaucheriae (Kützing) Peterson & FVAU & $* *$ & 4 & 3 & & + & + & & & \\
\hline Fragilaria vaucheriae (Kützing) Peterson fo. teratogene & FCVT & 1 & 4 & 3 & & & + & & & \\
\hline Frustulia crassinervia (Brebisson) Lange-Bertalot et Krammer & FCRS & $\mathrm{V}$ & 1 & 3 & + & + & + & + & + & + \\
\hline Gomphonema aff. affine Kützing & GAFF & & 4 & 2 & + & + & + & + & & + \\
\hline Gomphonema cymbelliclinum Reichardt et Lange-Bertalot & GCBC & & 4 & & & & & + & & \\
\hline Gomphonema gracile Ehrenberg & GGRA & $\mathrm{D}$ & 3 & 3 & & & + & + & + & + \\
\hline Gomphonema micropus Fricke & GMIC & $*$ & 3 & & + & & & & & \\
\hline Gomphonema olivaceoides Hustedt & GOLD & $*$ & 3 & 3 & + & & + & & & \\
\hline Gomphonema olivaceum var. minutissimum Hustedt & GOMI & $*$ & 3 & 3 & + & + & & & & \\
\hline Gomphonema parvulum (Kützing) Kützing & GPAR & & 3 & 3 & + & & & & & \\
\hline Gomphonema parvulum var. exilissimum Grunow & GPXS & $\mathrm{V}$ & 3 & 3 & + & + & + & + & + & + \\
\hline Gomphonema pseudotenellum Lange-Bertalot & GPTE & 3 & & & + & & & & & \\
\hline Gomphonema pumilum var. elegans Reichardt et Lange-Bertalot & GPEL & & & & + & + & + & & & + \\
\hline Gomphonema tergestinum (Grunow) Fricke & GTER & G & 4 & 3 & + & & + & & & + \\
\hline Gomphonema utae Lange-Bertalot et Reichardt & GUTA & $\mathrm{D}$ & & & & & + & & + & + \\
\hline Kobayasiella parasubtilissima (Kobayasi \& Nagumo) Lange-Bertalot & KOPA & & 1 & 3 & & & & & + & + \\
\hline Meridion circulare (Greville) Agardh & MCIR & $* *$ & 4 & 1 & & & + & + & + & + \\
\hline Meridion circulare var. constrictum (Ralfs) Van Heurck & MCCO & $* *$ & 4 & 2 & & + & & & & \\
\hline Navicula angusta Grunow & NAAN & 3 & 2 & 2 & + & + & & & + & + \\
\hline Navicula cryptotenella Lange-Bertalot & NCTE & & 4 & 2 & + & & & & & \\
\hline Navicula cryptotenelloides Lange-Bertalot & NCTO & $*$ & 4 & & & + & & & & \\
\hline Navicula exilis Kützing & NEXI & G & & & + & + & & + & & + \\
\hline Navicula gregaria Donkin & NGRE & $* *$ & 4 & 3 & + & & & & & \\
\hline Naviculadicta detenta Hustedt & NDET & 1 & & & + & & & & & + \\
\hline Naviculadicta difficillima Hustedt & NDIF & G & 2 & 3 & & & & & & + \\
\hline Naviculadicta parabryophila Lange-Bertalot & NDPA & & & & & & & + & + & + \\
\hline Naviculadicta schmassmannii (Hustedt) Werum et Lange-Bertalot & NSMM & 2 & 3 & & + & & & & & \\
\hline Naviculadicta suchlandtii Hustedt & NSUC & $\mathrm{V}$ & 3 & & & & + & + & + & + \\
\hline Neidium alpinum Hustedt & NALP & 3 & 2 & 3 & + & + & & + & + & + \\
\hline Neidium bisulcatum (Lagerstedt) Cleve & NBIS & 3 & 3 & 3 & & & & & & + \\
\hline Neidium longiceps (Gregory) Ross & NLGI & G & 2 & 3 & & & + & + & + & + \\
\hline Neofragilaria virescens (Ralfs) Williams \& Round & NFVI & & 3 & & + & + & + & + & + & + \\
\hline
\end{tabular}

(continued) 
Appendix. Continuation

\begin{tabular}{|c|c|c|c|c|c|c|c|c|c|c|}
\hline \multirow[t]{2}{*}{ Taxon } & \multirow[t]{2}{*}{ Code } & \multirow[t]{2}{*}{ R.L. } & \multirow[t]{2}{*}{$\mathrm{pH}$} & \multirow[t]{2}{*}{ Moist } & \multicolumn{2}{|c|}{$\mathrm{R}$} & \multicolumn{2}{|c|}{$\mathrm{S}$} & \multicolumn{2}{|c|}{$\mathrm{P}$} \\
\hline & & & & & EL & EP & EL & EP & EL & EP \\
\hline Nitzschia cf. acidoclinata Lange-Bertalot & NACD & $*$ & 3 & 3 & + & + & + & + & + & + \\
\hline Nitzschia cf. bryophila Hustedt & NIBR & $\mathrm{D}$ & & 4 & & & + & + & & \\
\hline Nitzschia dissipata (Kützing) Grunow & NDIS & $* *$ & 4 & 3 & + & + & & & & \\
\hline Nitzschia cf. elegantula Grunow & NELE & $*$ & & & & & & + & & \\
\hline Nitzschia cf. fonticola (Grunow) Grunow & NFON & $* *$ & 4 & 1 & + & & + & & + & + \\
\hline Nitzschia gracilis Hantzsch & NIGR & * & 3 & 1 & & & + & + & & \\
\hline Nitzschia aff. hantzschiana Rabenhorst & NHAN & $*$ & 3 & 4 & + & + & + & + & + & + \\
\hline Nitzschia inconspicua Grunow & NINC & $* *$ & 4 & 3 & + & & & & + & \\
\hline Nitzschia obtusa var. brevissima (Grunow) Van Heurck & NOBM & & & & & & & + & & \\
\hline Nitzschia perminuta (Grunow) Peragallo & NIPM & $*$ & 4 & 3 & + & & + & + & & \\
\hline Nitzschia sinuata var. tabellaria Grunow & NSIT & $\mathrm{V}$ & 3 & 3 & & & + & & & \\
\hline Nitzschia sp.1 & & & & & + & & & & & \\
\hline Nupela lapidosa (Krasske) Lange-Bertalot & NULA & $\mathrm{V}$ & 2 & 4 & + & + & + & & & + \\
\hline Orthoseira dentroteres (Ehrenberg) Round, Crawford \& Mann & ODEN & $\mathrm{V}$ & & & + & + & & & & \\
\hline Pinnularia borealis Ehrenberg & PBOR & $* *$ & 3 & 4 & + & + & + & + & + & + \\
\hline Pinnularia borealis var. tenuistriata Krammer & PBTE & & 3 & 4 & & & & & & + \\
\hline Pinnularia borealis var. sublinearis Krammer & PBSL & & 3 & 4 & & + & & & & \\
\hline Pinnularia frauenbergiana Reichardt & PFRA & $\mathrm{R}$ & & & & + & & & & \\
\hline Pinnularia marchica Ilka Schönfelder var. marchica & $\mathrm{PMCH}$ & & & & & & & & + & \\
\hline Pinnularia microstauron (Ehrenberg) Cleve & PMIC & $\mathrm{V}$ & 3 & 3 & + & & & & + & + \\
\hline Pinnularia microstauron var. rostrata Krammer & PMRO & & & & & & & & + & + \\
\hline Pinnularia peracuminata Krammer & PPEA & & & & & & + & & & \\
\hline Pinnularia perrirorata Krammer & PPRI & & 2 & & + & & + & + & + & + \\
\hline Pinnularia sinistra Krammer & PSIN & $*$ & 2 & & & + & + & + & + & + \\
\hline Pinnularia sp.1 & & & & & & + & & & & \\
\hline Pinnularia stomatophora (Grunow) Cleve & PSTO & G & 2 & 4 & + & + & & & & \\
\hline Pinnularia subcapitata Gregory & PSCA & $*$ & 1 & 3 & + & & & & & \\
\hline Pinnularia subcapitata var. elongata Krammer & PSEL & $*$ & 2 & 3 & & & + & & & \\
\hline Pinnularia subcapitata var. subrostrata Krammer & PSSR & $*$ & 3 & 3 & & & & + & & \\
\hline Pinnularia subrupestris Krammer & PSRU & G & & & & + & & & & \\
\hline Planothidium delicatum (Kützing) Round \& Bukhtiyarova & PTDE & $*$ & 5 & 3 & & + & & & & \\
\hline Planothidium frequentissimum (Lange-Bertalot) Lange-Bertalot & PTFR & $* *$ & & & + & & & & & \\
\hline Planothidium haynaldii (Schaarschmidt) Lange-Bertalot & PHAY & $\mathrm{D}$ & 4 & 3 & + & & & & & \\
\hline Planothidium lanceolatum (Brébisson) Lange-Bertalot & PTLA & $* *$ & 4 & 3 & + & & + & + & & \\
\hline Psammothidium bioretii (Germain) Bukhtiyarova et Round & PBIO & $\mathrm{V}$ & 3 & 4 & + & & & & & \\
\hline Psammothidium levanderi (Hustedt) Bukhtiyarova & PLVD & 3 & 3 & 3 & & + & & & & \\
\hline Psammothidium oblongellum (Oestrup) Van de Vijver & POBG & $\mathrm{V}$ & 3 & 3 & + & + & + & + & + & + \\
\hline Psammothidium oblongellum (Oestrup) Van de Vijver, teratogena & AOTG & 1 & 3 & 3 & & & & & + & \\
\hline Psammothidium rossii (Hustedt) Bukhtiyarova et Round & PROS & 2 & 3 & & & + & & & & \\
\hline Pseudostaurosira robusta Williams \& Round & PRBS & & & & & + & & & & \\
\hline Reimeria sinuata (Gregory) Kociolek et Stoermer & RSIN & $* *$ & 3 & 3 & + & + & + & & & \\
\hline Reimeria uniseriata Sala Guerrero \& Ferrario & RUNI & & & & & & + & & & \\
\hline Rossithidium nodosum (Cleve) Aboal & RNOD & 1 & 3 & & & + & & & & \\
\hline Rossithidium petersennii (Hustedt) Round \& Bukhtiyarova & RPET & 3 & 3 & & + & + & & & & \\
\hline Stauroforma exiguiformis (Lange-Bertalot) Flower, V.J. Jones et Round & SEXG & 3 & 3 & 2 & & + & + & + & + & \\
\hline Stauroneis cf. acidoclinata Lange-Bertalot \& Werum & SADC & & & & & + & + & & + & \\
\hline Stauroneis agrestis Petersen & STAG & $\mathrm{R}$ & & 4 & & + & & & & \\
\hline Stauroneis thermicola (Petersen) Lund & STHE & $*$ & 3 & 4 & & & + & & & \\
\hline Staurosira construens var. binodis (Ehr.) Hamilton & SCBI & $*$ & 4 & 2 & & + & & & & \\
\hline Staurosira pinnata Ehrenberg & SPIN & $* *$ & 4 & 3 & + & & + & & & \\
\hline Staurosira venter (Ehrenberg) Kobayasi & SSVE & $* *$ & 4 & 1 & + & + & + & + & + & + \\
\hline Surirella brebissonii var. kuetzingii Krammer et Lange-Bertalot & SBKU & $* *$ & 4 & 3 & & & & & & \\
\hline Tabellaria flocculosa (Roth) Kützing & TFLO & $* *$ & 2 & 3 & + & + & + & + & + & + \\
\hline Tabellaria flocculosa (Roth) Kützing fo. teratogene & TFLT & 1 & 2 & 3 & & & & & & \\
\hline Ulnaria acus (Kützing) Aboal & UACU & & & & & & + & & & \\
\hline Ulnaria ulna (Nitzsch) Compère & UULN & * & 4 & 2 & + & + & + & & & \\
\hline
\end{tabular}

Received: December 2010

Accepted: March 2011 